\title{
Knowledge Management in Libraries and Information Centers: A Bibliometric Perspective
}

\author{
Priti Jain \\ Professor, Department of Library and Information Studies \\ University of Botswana, Gaborone, Botswana
}

\begin{abstract}
The purpose of this paper is to provide a bibliometric perspective of Knowledge Management (KM) literature in libraries for the past 21 years (1998-2019), based on Web of Science core collection bibliographical database. The objectives of the paper are to examine a bibliometric profile of publications in the field of KM in libraries and analyze the emerging research trends in $\mathrm{KM}$ research in libraries and information centers through Keyword co-occurrence. This study used bibliometric and citation analysis methods to explore the profile and research trends in knowledge management research in libraries. A total of 83 sources were retrieved via Web of Science's core collection database using the terms "Knowledge Management, Libraries, Information centers, librarians, information professionals". Data was analyzed through Web of Science's Clarivate Analytics, then exported to Microsoft Excel and VoSviewer for production of images and graphs. Findings revealed that the most research outputs were produced in year 2018 mostly in article forms and the University of South Africa led in contribution to knowledge management research in libraries. Findings also determined top 10 prolific authors and publishing sources; most research were produced by United States, followed by South Africa. As most KM research is carried out on perceptions, predictions and benefits of KM in libraries and information centers not on KM practice in libraries and its impact on the quality of library services. This has implication on KM practice in libraries and information centers. Practicing librarians are unable to apply KM emulating success stories and best practices of libraries and information centers. Bibliometric studies on KM are too general, and to the best knowledge of the researcher, none of them so far gives a clear view of research trends of $\mathrm{KM}$ in libraries. Hence, this might be the first study to fill this gap, which only analyzed a sample of documents which are more relevant to the scope of the study.
\end{abstract}

Keywords: Bibliometric analysis, Knowledge management, Libraries, Information centers, Scientometric analysis, Web of Science, KM research trends. 
Jain, P. (2020) Knowledge Management In Libraries And Information Centers: A Bibliometric Perspective. Advances in Social Sciences Research Iournal, 7(4) 431-453.

\section{INTRODUCTION}

According to Mašić et. al., (2017: 127), "Knowledge management (KM) is not new but rather newly structured concept". KM is said to be an expanding field that has the potential to offer a unifying foundation for many other disciplines (Serenko, 2013). According to Serenko and Bontis (2013), KM is gradually progressing towards becoming a reference discipline that has both theoretical and practical impact. In fact, KM has appeared and been discussed in various journals, academic meeting/conferences and academic curricula; this positions it as an independent scientific discipline (Dattero, 2006; Lang et. al., 2010; Dwivedi et. al., 2011; Serenko, 2013; Serenko et. al., 2010). This is also affirmed by Fteimi and Lehner (2016:5), who note that "KM has already reached the level of a scientific discipline and attracts increasing interest in research and practice." As a result, Knowledge is gradually being recognized as the most valuable asset in modern organizations and a key resource for a knowledge-based economy (Abualoush, et. al., 2018; Lee and Chen, 2012; Iqbal and Mahmood, 2012). Knowledge has been commonly recognized as the most valuable and strategic asset of an organization to gain and sustain competitive edge over its competitors. Abualoush et. al. (2018:283), assert that knowledge "is the vital and effective tool through which organizations are able to fulfil their tasks and carry out their activities in order to achieve their goals efficiently." Hence, the need to manage knowledge effectively have a comprehensive knowledge management infrastructure within the organization. Furthermore, Maruf and Zhou (2015) affirm that knowledge generates innovations and transforms them into products and processes that enhances economic development. Global economy and sustainable development are based on knowledge resource. As a result, the global economy is known as a knowledge-based economy, where a country's growth is dependent on the quality, quantity and the accessibility of information and knowledge. Due to the advancement of technology, there is unremitting flow of information and knowledge resulting into information explosion. "Knowledge Management is an attempt to cope with the explosion of information and capitalize on the increased knowledge in the workplace" (Evans and McKinley, 2010:1098). According to O'dell, Grayson and Essaides (1998:6), KM is a "conscious strategy of getting the right knowledge to the right people at the right time and helping people share and put information into action in ways that strive to improve organizational performance". These days, "successful and thriving organizations are those which create or gain new knowledge and convert it into applicable methods for improving their activities and performance" (Akhavan, Ramezan and Moghaddam, 2013:129). The focus of this paper is to provide a bibliometric perspective of KM in libraries and information centers. The paper analyzed the KM research to get insight into how libraries and information centers are practicing KM being information providers in the field of libraries and other information centers.

\section{BIBLIOMETRIC ANALYSIS LITERATURE IN KM}

Increasingly, bibliometrics are being used to measure and rank research output in a particular subject area. "A bibliometric technique is a simple statistical method of bibliography counting to evaluate and quantify the growth of research topics" (Ahmadi and Nazim, 2018:1). However, Gaviria-Marin, Merigó and Popa, (2018) expound that bibliometric analysis comprises of techniques that visualize both the qualitative and quantitative changes in specific research disciplines. Durieux and Gevenois (2010:342), further explain that bibliometrics involves: quantity indicators, which measure the productivity of a particular researcher; quality indicators, which measure the quality (or "performance") of a researcher's output; and structural indicators, which measure connections between publications, authors, and areas of research. Traditionally, libraries and information managers were using bibliometric techniques in their day-to-day administration. In today's digital 
environment, bibliometric studies have been often conducted to analyze the literature and explore the research trends in any research field (Ahmad, JianMing and Rafi, 2018). Bibliometric analysis is one of the popular methods employed in recent days for identification of core documents in various subject fields for a particular scientific community to understand the information requirements of users. It became prominent because of the need to measure the effects of the large investments going into the research and development. Bibliometrics has its origins as early as the beginning of the $19^{\text {th }}$ century, but, it became data-driven in 1964 with the introduction of the science citation index (Kokol et al., 2015:4). It is also useful in collection management in libraries and research and publication management in academic and research institutions and it determines highflyers and productive researchers in a specific subject. Several bibliometric and content analysis studies have been conducted worldwide as shown in Table 1.

As depicted on Table 1, several studies have been conducted to identity the research trends within the 'Knowledge Management' discipline over the years. These studies have employed various techniques and databases to collect and analyze the bibliographic data on KM publications. The most commonly used database as shown on Table 1 is Web of Science (WoS). Majority of the studies conducted an analysis based on all the sources in one database while a few studies restricted their bibliometric analysis to a specific journal or citation index. This study also followed a similar pattern by adopting the use of Web of Science database due to its convenience in terms of accessibility to the researcher. Unlike Scopus database, WoS was easily accessible through the University of Botswana network. The use of WoS is also supported by Dwivedi et al. (2011) and Chao et al. (2007), who explains that majority of IS journals are included either within the Science Citation Index (SCI) or within the Social Science Citation Index (SSCI). Consequently, one can search and locate a significant proportion of the published material on KM across various disciplines using WoS. In addition, "restricting the search activities to a single publication database removed many of the potential problems of duplication inherent in the use of multiple data sources" (Dwivedi et al., 2011:45). It is worth noting that the publications presented in Table 1 above, do not follow a similar pattern in terms of the time period selected for limiting the search for publications in KM. Seven publications set their time limit for over 30 years, while 11 studies set their research period below 20 years. However, majority of these studies failed to give an explanation of how or why they selected that particular timeframe. Apart from Gaviria-Marin, Merigó and Popa, (2018) and Kör (2017) whose choice for the publication period selected was clear. Gaviria-Marin, Merigó and Popa, (2018) conducted their analysis "between" 1997-2016. This was because the Journal of Knowledge Management (JKM) under study was celebrating its 20th anniversary (having been established in 1997). Hence the authors sought to show an updated analysis of the journal's publications to provide a general overview of the journal, focusing on a bibliometric analysis of its publications between 1997 and 2016. On the other hand, Kör (2017) limited the search "between" 2010-2015 because the study aimed at updating the findings of Serenko and Du-may (2015) whose study was limited between 1997 and 2009. These two studies depict that the section of the time frame can be based on or linked to the aim of the study. The lack of consistency or scientific explanation as to how the search period is selected, it is quite a worrisome factor in most bibliometric analysis studies. 
Jain, P. (2020) Knowledge Management In Libraries And Information Centers: A Bibliometric Perspective. Advances in Social Sciences Research

Table 1: Bibliometric/ Scientometrics/ Citation Analysis Studies on KM

\begin{tabular}{|c|c|c|c|c|c|}
\hline Author & $\begin{array}{c}\text { Focus/ } \\
\text { Keywords }\end{array}$ & Database & $\begin{array}{c}\text { Articles } \\
\text { surveyed }\end{array}$ & $\begin{array}{c}\text { Time period } \\
\text { limitation }\end{array}$ & Country \\
\hline $\begin{array}{l}\text { Gaviria-Marin, } \\
\text { Merigó, and Baier- } \\
\text { Fuentes, (2019) } \\
\end{array}$ & $\begin{array}{c}\text { KM at organizational } \\
\text { level } \\
\text { Business economics. }\end{array}$ & Web of Science & 6155 & $1961-2015$ & Spain \\
\hline $\begin{array}{l}\text { Gaviria-Marin, } \\
\text { Merigó and Popa, } \\
(2018)\end{array}$ & JKM & $\begin{array}{l}\text { Scopus-Journal of Knowledge } \\
\text { Management (JKM) }\end{array}$ & 1068 & $1997-2016$ & $\begin{array}{l}\text { Chile and/ } \\
\text { Spain }\end{array}$ \\
\hline $\begin{array}{l}\text { Ahmad, JianMing } \\
\text { and Rafi, (2018) }\end{array}$ & KM in LIS & Web of Science & 6,258 & $1900-2017$ & China \\
\hline $\begin{array}{l}\text { Ali, Malik and Raza, } \\
\text { (2018) }\end{array}$ & Knowledge Sharing & Web of Science & 3,222 & $1990-2016$ & India \\
\hline $\begin{array}{l}\text { Alajmi and Alhaji, } \\
\text { (2018) }\end{array}$ & KM & $\begin{array}{c}\text { Scopus-Focused on Journal of } \\
\text { Information and Knowledge } \\
\text { Management only) }\end{array}$ & 475 & $2002-2016$ & Kuwait \\
\hline $\begin{array}{c}\text { Ahmadi and Nazim, } \\
\text { (2018) }\end{array}$ & KM in LIS & Web of Science & 8,069 & $1986-2016$ & India \\
\hline Wang et al., (2018) & KM & Web of Science & 7,628 & $1974-2017$ & China \\
\hline Ahmed, (2017) & $\begin{array}{l}\text { KM, Tacit and explicit } \\
\text { knowledge- Refined to } \\
\text { Business management } \\
\text { and Computer Science }\end{array}$ & Web of Science, Esearch & 9,687 & $2003-2016$ & USA \\
\hline Kör, (2017) & KM & $\begin{array}{l}\text { Google Scholar (Harzing's } \\
\text { Publish or Perish tool) }\end{array}$ & 109 & $2010-2015$ & Turkey \\
\hline $\begin{array}{l}\text { Akhavan et al., } \\
\text { (2016) }\end{array}$ & KM & Web of Science & 3,198 & $1980-2014$ & Multiple \\
\hline $\begin{array}{l}\text { Fteimi and Lehner, } \\
\qquad(2016)\end{array}$ & KM & $\begin{array}{l}\text { Proceedings of the European } \\
\text { Conference on Knowledge } \\
\text { Management (ECKM)-Scopus }\end{array}$ & 755 & $2006-2013$ & German \\
\hline Kokol et al., (2015) & KM in Organizations & Scopus & 10,599 & $1977-2014$ & Slovenia \\
\hline Qiu and Lv, (2014) & KM & Web of Science & 12,925 & 1993-2012 & China \\
\hline $\begin{array}{c}\text { Sedighi and } \\
\text { Jalalimanesh, } \\
(2014) \\
\end{array}$ & KM & Web of Science & 50,862 & $2001-2010$ & Iran \\
\hline $\begin{array}{l}\text { Lee and Chen, } \\
(2012)\end{array}$ & KM & & 10,974 & $1995-2010$ & Taiwan \\
\hline $\begin{array}{c}\text { Iqbal and Mahmood, } \\
(2012)\end{array}$ & KM & $\begin{array}{l}\text { Information Systems } \\
\text { Management Journal }\end{array}$ & 18 & $1999-2011$ & Pakistan \\
\hline Dwivedi et al., 2011 & KM & Web of Science & 1,043 & 1974-2008 & $\begin{array}{l}\text { United } \\
\text { Kingdom }\end{array}$ \\
\hline Sohail, (2008) & KM in LIS & $\begin{array}{c}\text { Library Information Science } \\
\text { Abstract (LISA)-Physical }\end{array}$ & 1,227 & 1999-2006 & India \\
\hline Onyancha, (2006) & $\begin{array}{c}\text { KM in South Africa (KM } \\
\text { and IM) }\end{array}$ & $\begin{array}{l}\text { Current and Completed } \\
\text { Research (C\&CR) and the } \\
\text { Index to South African } \\
\text { Periodicals (ISAP) databases }\end{array}$ & 554 & - & $\begin{array}{l}\text { South } \\
\text { Africa }\end{array}$ \\
\hline Gu, (2004) & $\begin{array}{c}\text { KM, Knowledge } \\
\text { discovery, Knowledge } \\
\text { sharing }\end{array}$ & Web of Science & 1,407 & All years & China \\
\hline $\begin{array}{c}\text { Chauvel and } \\
\text { Despres, (2002) }\end{array}$ & KM and Survey & $\begin{array}{c}\text { Anbar (MCB), ProQuest } \\
\text { (UMI), Ebsco, Social Science, } \\
\text { Citation Index }\end{array}$ & 59 & $1997-2001$ & France \\
\hline
\end{tabular}


One of the gaps identified in the studies presented in Table 1, is that they failed to establish content relevancy. Rather they analyzed all documents retrieved based on the availability of the keywords used within the documents. As can be seen, most of the publications in Table 1 retrieved and analyzed a huge number of articles on KM. However, these studies did not screen the retrieved documents for content relevancy. This is also affirmed by Wang et al., (2018), who states that 7628 articles were assumed to be in some way related to KM were analyzed. This shows that most bibliometric studies are conducted on the assumption of relevancy based on appearance of keywords in the documents retrieved. Thus, reducing the trustworthiness of the findings. Moreover, the focus of these studies was more general to research trends in 'KM publications', 'KM in LIS' and 'KM in Organizations'. Only two studies by Onyancha (2006), and Gaviria-Marin, Merigó, and BaierFuentes, (2019) were specific to KM trends in South Africa and Business economics respectively.

Therefore, this current study deviates from this research trends by focusing the bibliometric analysis to KM publications in libraries. None of the studies provided such analysis of research trends of KM in Libraries. This is so, because today KM is considered as one of the key drivers in any organization, especially in libraries which are expected to be knowledge hubs. Furthermore, this current study ensured content relevancy and trustworthiness of findings by refining the search output through a manual process of reading the abstract. Abstract analysis ensured that only those documents that discussed KM in libraries or information centers were included in the analysis of the study. This exclusion criteria was also followed by Bem and Coelho (2013), who conducted a systematic literature review on applications of KM in LIS. After retrieving 453 articles between 2007 and 2013, the authors conducted an abstract and text analysis which reduced the articles to 147. Bem and Coelho's (2013) approach shows that it is not quantity that matters but rather quality of the results. Therefore, this method enhances the validity and trustworthiness of the findings.

Another gap that this current study sought to fill, is the fact that there is scarcity of bibliometric studies on KM in libraries especially in Africa. As can be seen on Table 1, only one bibliometric study on KM in South Africa was conducted. And none so far has been conducted specifically on KM in libraries. Moreover, Sedighi and Jalalimanesh (2014), state that KM publications in general focus on knowledge in organizations, knowledge-based, theory of the firm, strategy, and knowledge creation. While, Bem and Coelho (2013) revealed that the following categories of research area are more prominent in librarianship and information science: Semantic Web/Ontologies, New Professional Roles of Information and Libraries, Competence of Librarianship and Information Science in KM, Traditional Library Services, Theoretical Aspects of KM and/or IS, Management Point of View, KM Models and Methodologies, Organizational Learning /Innovation, Data Banks/Bases and Knowledge, Km Tools and Practices. In addition, Sohail (2008) also revealed that the highest percentage of documents identified in the field of KM in LIS were: 'Knowledge Management' $(\mathrm{n}=440$, 35.85\%), 'Business Management' $(n=177,14.42 \%)$, 'Information Management' ( $n=56,4.56 \%)$, and 'Library Management' $(n=50,4.07 \%)$. These research areas show that KM is prominent in LIS. However, there is no clear depiction on research trends specific to KM in libraries. Rather majority of the studies focus on LIS in general. Hence there was a need for this current study. The following section outlines the importance of KM in libraries. 
Jain, P. (2020) Knowledge Management In Libraries And Information Centers: A Bibliometric Perspective. Advances in Social Sciences Research Iournal, 7(4) 431-453.

\section{IMPORTANCE OF KNOWLEDGE MANAGEMENT IN LIBRARIES}

Knowledge has become a strategic weapon for the survival of all types of organizations including libraries and information centers to attain and sustain a competitive edge over their competitors in the global market. Libraries and information centers are knowledge-intensive organizations, knowledge management is of vital importance to them. Rooi and Snyman (2006) Koloniari and Fassoulis (2017), Mavodza and Ngulube (2011) concur that the advancement of ICTs together with the exponential growth of the information and knowledge society has transformed the ways in which services are provided in academic libraries, thus making knowledge management an imperative. As a result, this has attracted researchers to study various aspects of knowledge management in libraries. Examples include a study by Nazim (2013), who studied the librarians' perceptions of Knowledge Management in Indian academic libraries. Nazim's study revealed that librarians had positive attitude towards the applications of knowledge management into academic library practice. However, most of them focus on the use of technology to capture and use explicit knowledge, rather than sharing and using more intangible knowledge embedded in the employees. Sarrafzadeh, Martin and Hazeri (2010) and Nazim (2013) also concur that KM has the potential to bring academic libraries closer to their parent organization and it may help them to survive in an increasingly challenging information environment.

It was also revealed that "Lack of understanding of knowledge management concepts, knowledge sharing culture, top management interest, incentives and rewards, financial resources and information technology infrastructure are perceived as the major barriers for incorporating knowledge management into academic library practice" (Nazim, 2013:63). Similar findings were established by Nazim and Mukherjee (2011) who stated that librarians in India focused mainly on management of explicit knowledge and their roles were perceived as basic information management undertakings.

Literature further reveals that knowledge management practices in libraries do exist. This is evidenced by a qualitative study conducted in Kenya by Sirorei and Fombad (2019). Their study revealed that knowledge management processes were utilized at St Paul's University Library, although to varying degrees, and the knowledge management processes were not formalized. Therefore, Sirorei and Fombad (2019:7) recommended "that knowledge management processes should be formally incorporated at academic libraries in Kenya as this will increase the effectiveness and efficiency of the academic libraries".

Similarly, several studies on KM aspects have been conducted in academic libraries. This include studies by (1) Agarwal and Islam (2014), who investigated the technologies that would be of value to libraries as they implement KM; (2) Ugwu and Ekere (2017) examined the knowledge management activities of librarians in university libraries in Nigeria and established that librarians were quite involved in knowledge identification, acquisition, creation and dissemination; (3) Awodoyin et el. (2016), Ugocha, Igwe and Ibenne (2018) and Ajie (2019), who explored Knowledge sharing practices among librarians; (4) Asogwa (2012), who examined the contributions of librarians in knowledge management, and the implications for academic librarians; (5) Rusuli, Tasmin, and Takala, (2012), who explored the factors that support Knowledge Management Practice at Malaysian university libraries; (6) Ali and Khan (2017) who investigated the knowledge management strategies adopted by the libraries of central universities in India; (7) Wanangeye, and George (2016), who assessed and evaluated the knowledge management practices and 
performance in academic libraries in Kenya; and (8) Jain (2013) who explored KM practices in Southern African Development Community (SADC) university libraries. As can be seen from the literature, KM research in libraries is being embraced in various countries. Hence, the need for a bibliometric analysis to establish the research trends that can be used to identify future opportunities for researchers and libraries.

In the same vein, literature has revealed that there are a lot of knowledge management opportunities for librarians (Abell; 2000; Barron, 2000; Choo, 2000; Koina, 2003; Poonkothai, 2016). These opportunities are further categorized by Rooi and Snyman (2006) as follows; Facilitating an environment conducive to knowledge sharing; Managing the corporate memory; Transfer of information management and related skills to a new context linked to business processes and core operations; Development of corporate information literacy; and Management of information in a digital/electronic environment. Rooi and Snyman (2006:261) further assert that KM research is important as it "may assist in the improvement of teaching and research in library and information science. Additionally, librarians may become aware of the opportunities and acquire guidelines on how to attain the necessary requirements towards enhancing their role and ultimately boosting their image."

Based on the challenges faced by librarians in KM and the shortcomings of KM practices identified in the above studies, it is imperative for one to establish a clear picture of KM publications in libraries. This will raise awareness to both practitioners and researchers in the research trends and stimulate effective policy making and implementation of strategies to improve KM practices in libraries. In addition, "the success of academic libraries in the competitive and challenging knowledge environment depends on their ability to utilize information and knowledge to meet the needs of the academic community" (Rooi and Snyman, 2006:261). Therefore, the importance of KM research in libraries cannot be undermined.

\section{OBJECTIVES}

The main purpose of the study is to provide a bibliometric perspective of knowledge management literature in libraries by comparing the research undertaken during 1998 to 2019. To accomplish the purpose, the following specific objectives were pursued:

- To examine a bibliometric profile of publications in the field of KM in libraries (published items per year, most productive research institutions, most prolific authors and publication sources, contribution of the countries, citations per year, co-citation, co-authorship and bibliographic coupling analysis).

- To analyze the emerging research trends in KM research in Libraries and information centers through Keyword co-occurrence.

\section{METHODOLOGY}

This study used bibliometric and citation analysis methods to explore the profile and research trends in knowledge management research in libraries and information centers. The paper investigated the sources downloaded from ISI Web of Sciences core collection database from the following indexes=SCI-EXPANDED, SSCI, A and HCI, CPCI-S, CPCI-SSH, BKCI-S, BKCI-SSH, ESCI, CCREXPANDED, IC. The term "knowledge management" was searched by selecting the publication period from 1998 to 2019, document types, using only records in English. The time period 1998- 
Jain, P. (2020) Knowledge Management In Libraries And Information Centers: A Bibliometric Perspective. Advances in Social Sciences Research Iournal, 7(4) 431-453.

2019 was opted for because KM became more popular in past two decades. The study had sought to establish KM research activities in libraries that have taken place in the past two decades. A search string that included all the disciplines retrieved 107,042 from Web of Science bibliographical database articles, which shows KM is a multi-disciplinary subject. A total of 2, 854 information sources were retrieved from Web of Science bibliographical database using the search string "Knowledge-Management AND Libraries OR Information centers". While a total of 2,881 were retrieved using the second search string, "Knowledge-Management AND Librarians OR Information professionals AND Libraries". Through the Web of Science function for combining search results, the above search strings resulted in 310 sources. The combination function was used as it helps to limit the sources to the most relevant documents based on the keywords search. These 310 sources were further analyzed through abstract screening.

The researcher used only those articles, which discussed knowledge management issues in the library environment. After title and abstract analysis, 227 records were not found relevant to libraries and information centers, hence, they were further excluded from the study. Thus, only 83 records were found relevant, which are used through-out the paper to provide bibliometric perspective of KM research in libraries and information centers. Data was analyzed through Web of Science's Clarivate Analytics, while graphics were created using Microsoft Excel. For visualization purposes and further bibliometric analyses, VOSviewer version 1.6.13, was used to conduct cocitation, co-authorship, bibliographic coupling and co-occurrence analysis.

This study had two major limitations:

- Firstly, it used only Web of Science's Core collection database, which is not linked with all other databases. Due to the above restriction, many research outputs in knowledge management are bound to be missed that are published in libraries and information centers field. This paper could be more comprehensive and enriched, if a database like Scopus could be used to search KM literature. Elsevier's Scopus is the largest abstract and citation database of peer-reviewed literature. The Scopus was not used because the researcher did not have access to the database.

- Secondly, this research was limited only to 4 types of document categories: 1 articles, 2 book chapters, 3 conference papers, and 4 . book reviews.

\section{RESULTS AND DISCUSSION}

The results are based on 83 records in knowledge management in the field of libraries and information centers. The following elements are examined: publications per year, most productive research institutions, prolific authors, publication sources, contribution by countries, collaboration research, co-citation, co-authorship, bibliographic coupling and co-occurrence analysis. Majority of the documents retrieved were journal articles $(n=69,83 \%)$; followed by conference proceedings $(n=6,7 \%)$ and book chapters $(n=7,8 \%)$. There was only one book review within the sample. This shows that journals are making more impact in the field of KM and librarianship.

This research output is also similar to other studies, which also revealed that journal articles and conference proceedings are the top main types of publications for KM research (Ali, Malik and Raza, 2018; Kokol et al., 2015). However, it is important for research in this field to take more dominance in conference platforms as it enhances and creates debates among professionals. This opens doors 
to policy changes, development of practice-based strategies and therefore, research is transformed into practice rather than just theory.

\section{Distribution of Publications by Year}

Findings pertaining to publications per year show that there was no publication in the years 1998 and 1999, which has not been captured in Figure 1. In the field of KM research activity has been very low from the year 2000-2005. This may be attributed to the fact that KM in libraries maybe still be at its infancy, since KM research only got popular in the last two decades. However, there was a rise in 2006, when 8 articles were published. Notwithstanding, the statistics dropped again from 2007-2014, when less than four articles where published each year. Since 2015 ( $n=7,8 \%)$, there has been a rise in the publication of KM research in libraries each year as shown in Figure 1 below. The year 2018 has the most publications in this field by 14 (17\%) articles. As of June 2019, publications were at $13 \%(n=11)$. However, it is gratifying to note that $13 \%$ was only in six months, the number is most likely to rise at the end of the year 2019. These statistics, imply that increasingly, researchers are gaining interest in studying $\mathrm{KM}$ in libraries. It is hoped that this bibliometric analysis will generate interest among various researchers to assess $\mathrm{KM}$ in libraries. As a result, it is predicted that there will be more research activities and publications per year in this field as is the trend for the past four years.

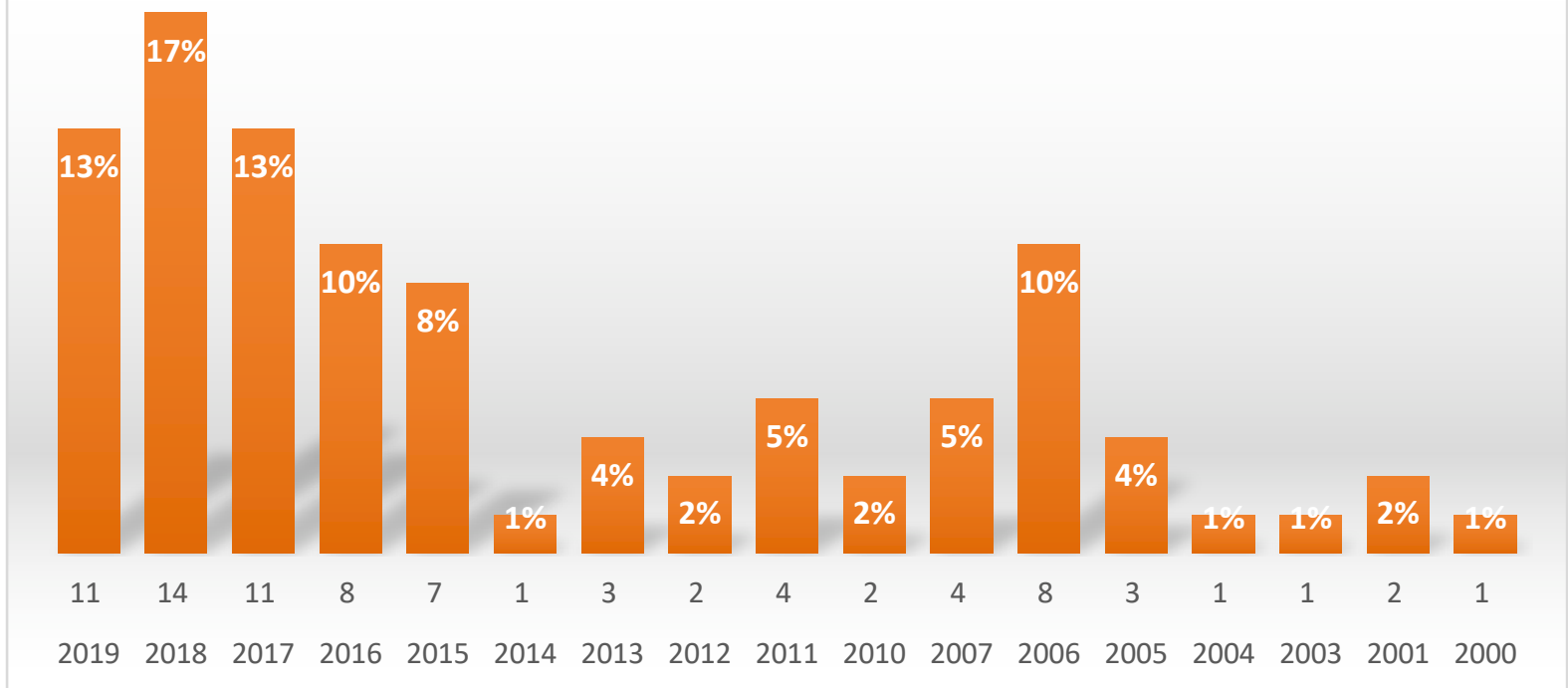

Figure 1: Publications per Year

Source: Web of Science database, June 2019

\section{Productive Institutions in KM}

As shown in Table (2) the most productive research institution in the field of 'KM in Libraries' is the University of South Africa (n=8,10\%). However, a closer look at these sources revealed that five of the eight sources linked with University of South Africa, were addressing issues of KM in federal university libraries in Nigeria. This may be attributed to the fact that the writers of the papers could have been PhD students or Lecturers/Researchers at the University of South Africa. This shows that researchers in Africa are taking the issues of KM in libraries very seriously. This is also evidenced by appearance of organizations in Africa such as, University of Nigeria $(n=3,4 \%)$ and University of Pretoria $(n=3,4 \%)$. 
Jain, P. (2020) Knowledge Management In Libraries And Information Centers: A Bibliometric Perspective. Advances in Social Sciences Research Iournal, 7(4) 431-453.

Table 2: Organization Enhanced

\begin{tabular}{|l|c|c|c|}
\hline \multicolumn{1}{|c|}{ Organization } & Documents & Citation & Total Link Strength \\
\hline University of South Africa & 8 & 1 & 8 \\
\hline Simmons College & 4 & 20 & 10 \\
\hline Aligarh Muslim University & 3 & 5 & 0 \\
\hline Japan Advanced Institute of Science Technology & 3 & 9 & 5 \\
\hline University of Athens & 3 & 12 & 8 \\
\hline University of Nigeria & 3 & 1 & 4 \\
\hline University of Pretoria & 3 & 14 & 1 \\
\hline Banaras Hindu University & 2 & 5 & 0 \\
\hline Special Library Association & 2 & 0 & 0 \\
\hline Universidad De La Habana & 2 & 0 & 0 \\
\hline
\end{tabular}

Source: Web of Science database and VOSviewer, June 2019

Despite the University of South Africa having the highest number of documents published on 'KM in Libraries', it has very low citations (1) as compared to other universities with few publications (Table 2). However, the link strength with other universities came second (link strength=8) to Simmons College which has the highest citation score of 20, highest link strength (of 10) but only have four publications. The University of Pretoria only has three publications, but has the second highest citations of 14, but weak link strength. On the other hand, University of Athens also has three publications but with a stronger link strength of 8 and total citations of 12 . As per the findings in Table 2, Simmons College has been enhanced more than any other organizations. These findings show that, though the University of South Africa has more publications, Simmons College is in the lead, due to having published KM research in libraries before University of South Africa did. Hence Simmons College has enhanced visibility in KM research.

\section{Authorship Patterns}

The most prolific author in writing on KM in libraries is C. I. Ugwu with four articles. However, a coauthor analysis as shown in Table 3 below, reveals that 4 of his articles were co-authored. It is interesting to note that C. I. Ugwu is affiliated with the University of South Africa but his research is based on federal university libraries in Nigeria. Thus, there is a possibility that South Africa may be enhanced more than Nigeria (as depicted on Table 2), whereas, the actual research was done in Nigeria. As a result, giving a wrong impression that there is more research activity on 'KM in Libraries' taking place in South Africa. On another note, despite Ugwu having the highest number of documents, the author is one of those with the least citations (1).

This may be attributed to the fact that the author's documents were published in 2018 and 2019. The second most prolific authors are K. Fassoulis and M. Koloniari, who have co-authored three papers on knowledge creation and knowledge management perceptions in academic libraries. Both authors are affiliated with Universities in Greece. Though they have a total of 12 citations, their 2017 paper received 10 citations as compared to 2018 and 2019 papers, which had one citation each. This shows that citations are accumulated over time and hence, the visibility of once research is increased over time. Thus, a quality paper may be expected to accumulate more citations over time. Failure to do so may indicate that the paper is of poor quality; the paper is not properly indexed; the abstract is lacking; hence, does not attract readership; or the author failed to establish relevant keywords to enable easy retrieval and identification in one's field of discipline. 


\section{Table 3: Most Prolific Authors in 'KM in libraries'}

\begin{tabular}{|c|c|c|}
\hline Authors & Documents & Citations \\
\hline Onyancha, O. B. & 2 & 1 \\
\hline Ugwu, C. I. & 4 & 1 \\
\hline Vraimaki, E. & 2 & 2 \\
\hline Ahmad, K. & 2 & 4 \\
\hline Nazim, M. & 2 & 5 \\
\hline Fassoulis, K. & 3 & 12 \\
\hline Koloniari, M. & 3 & 12 \\
\hline Agarwal, N. K. & 2 & 20 \\
\hline Ikeda, M. & 2 & 20 \\
\hline Islam, M. A. & 2 & 20 \\
\hline
\end{tabular}

Source: Web of Science database, June 2019

A co-author analysis was conducted to establish the authorship patterns. The minimum number of documents of an author was set to ' 2 ', while the minimum number of citations was set to ' 1 '. Of the 143 authors, only 10 authors met the threshold as shown on Table 3 . As shown in Figure 2, authors who have the most collaboration with others are highlighted red (cluster 1) and green (cluster 2). It is noteworthy that the authors in cluster 1 have the highest number of citations, though they have only two collaborated publications as compared to those with more than two documents in this network.

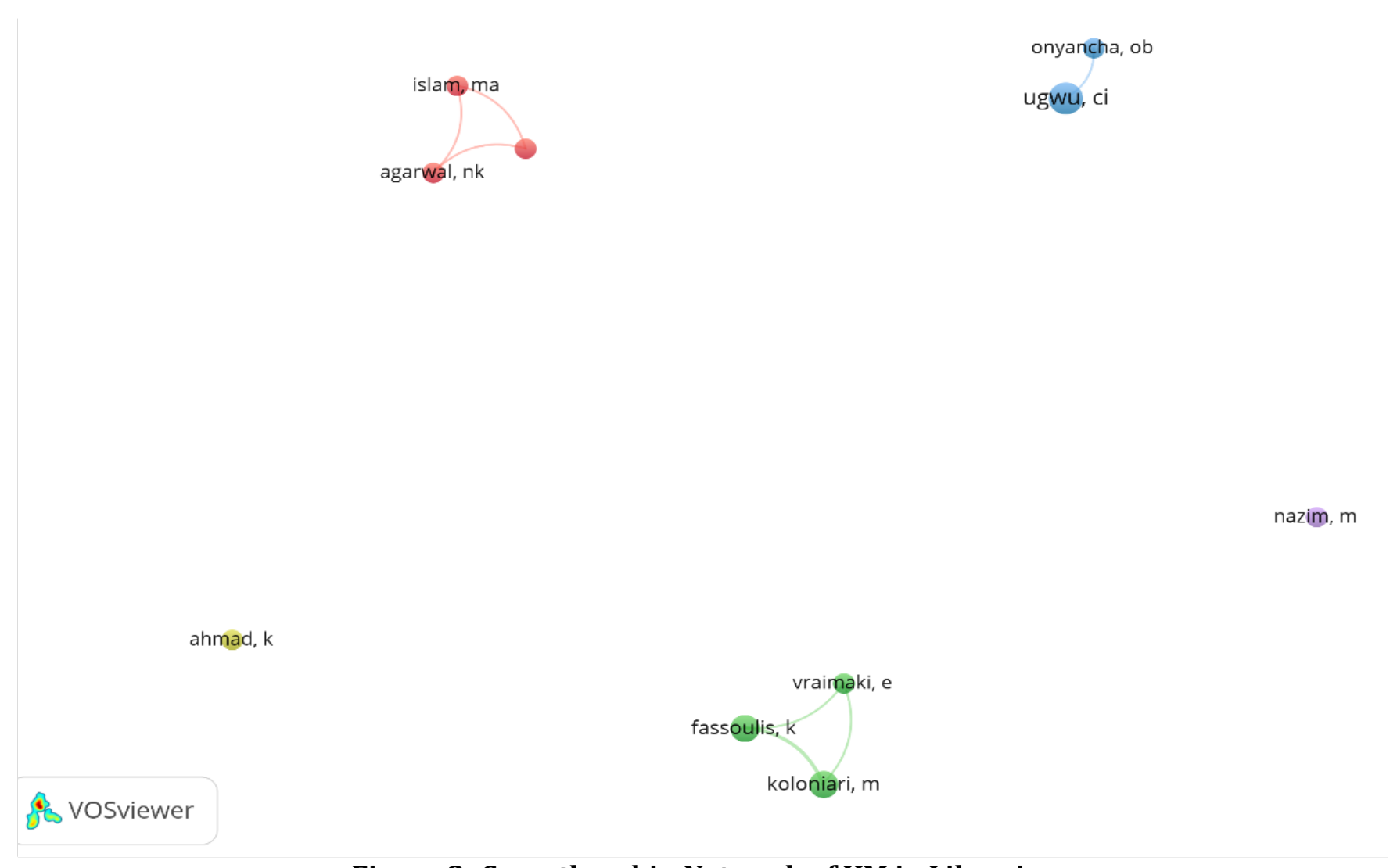

Figure 2: Co-authorship Network of KM in Libraries 
Furthermore, the distance between the authors in the network and the lack of linkage in Figure 2 above, shows that there is minimal collaboration among the top authors doing research on 'KM in libraries'. This is also evidenced by Figure 3 which shows that single authorship is preferred by most authors. It is also apparent that Ahmad, K. and Nazim, M. co-authored two papers each with different authors but they are not linked to anyone within the network. Figure 2 also shows that though Ugwu, C. I. has co-authored 4 papers, He only has one link with Onyancha, O. B., who has co-authored two papers. This may imply that the other authors who co-authored with Ugwu, C. I., may have not written any other papers relating to KM in libraries.
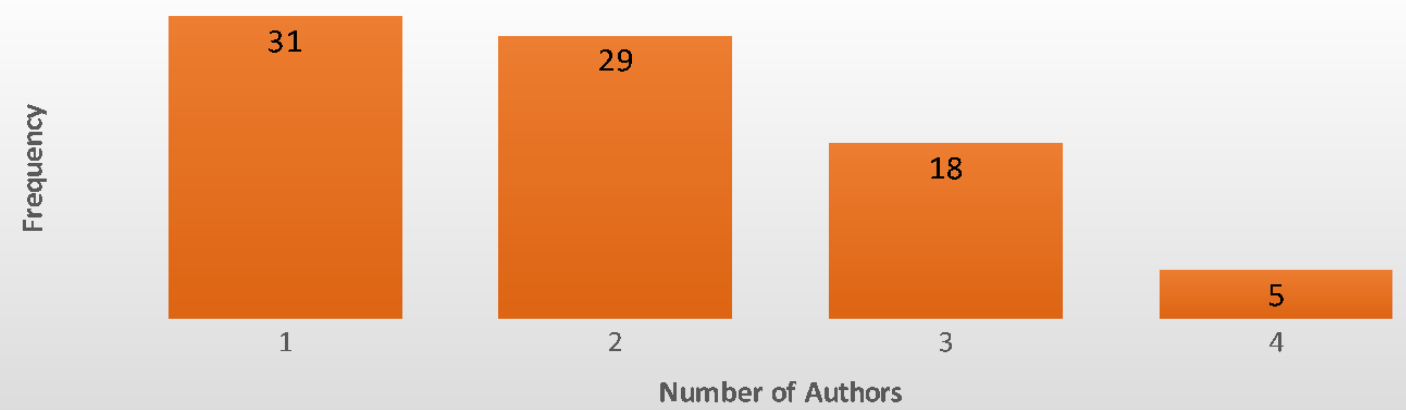

Number of Authors

Figure 3: Distribution of KM publication based on author(s)

Source: Web of Science database, June 2019

On the other hand, Figure 3 further shows that KM researchers in library and information centers mostly prefer co-authoring in pairs of two $(n=29,35 \%)$ and three $(n=18,22 \%)$. Only five articles were co-authored by four authors. Thus, it is evident that authors writing in the field of KM in libraries have been making efforts to collaborate as a total of $52(63 \%)$ articles were written by more than one author. Only 31 (37\%) articles were single-authored. A closer look at the articles shows that most of the researchers who co-authored are either from the same organization or different organizations in the same country. This is also evidenced by Figure 2, which shows that there is no cross links between co-authors. Similarly, Figure 4 shows that there are no links or collaboration between countries. It is therefore evident that there is need for researchers studying $\mathrm{KM}$ in libraries to network during conferences and co-author comparative studies between different countries. This will expand research in the field of KM in libraries and also allow organizations to benchmark or learn from different backgrounds. Co-authoring or collaborative research between countries will also facilitate development of best practices strategies to be adopted in the field of $\mathrm{KM}$ in libraries. This implies that collaboration is vital in research. Figure 4 presents the country coauthorship network. 


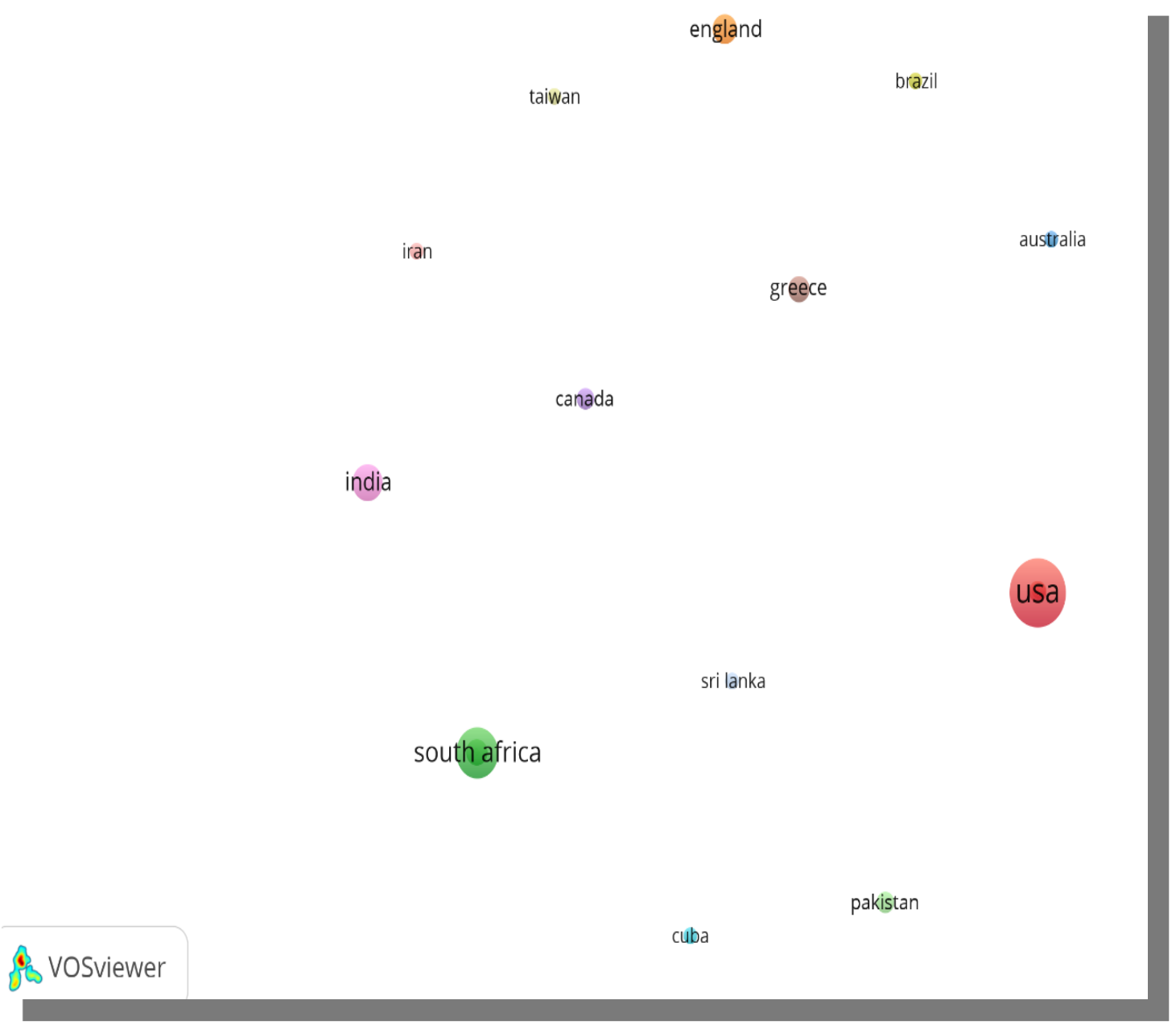

Figure 4: The country co-authorship network.

\section{Most Productive Publishers}

Table 4 below shows the ten most prolific publication sources. Based on the findings, it was evident that most research output is disseminated through journal publication (appearing 7 times in the table below, Conference Proceedings (appearing 2 times) and Book series (appeared only once). Though book series publication only appeared once on the above list (Table 4), 'Chandos Information Professional Series' appears to be at par with two journals (Journal of Librarianship and Information Science and Library Management) which have published four articles each. These are followed by other six journals with three (4\%) publications each. 
Jain, P. (2020) Knowledge Management In Libraries And Information Centers: A Bibliometric Perspective. Advances in Social Sciences Research Iournal, 7(4) 431-453.

Table 4: Top 10 Publishers

\begin{tabular}{|c|c|c|}
\hline Publication Source & Count & Percentage \\
\hline Chandos Information Professional Series & 4 & $5 \%$ \\
\hline Journal of Librarianship and Information Science & 4 & $5 \%$ \\
\hline Library Management & 4 & $5 \%$ \\
\hline ASLIB Proceedings & 3 & $4 \%$ \\
\hline Electronic Library & 3 & $4 \%$ \\
\hline DESIDOC Journal of Library Information Technology & 3 & $4 \%$ \\
\hline Journal of Academic Librarianship & 3 & $4 \%$ \\
\hline Journal of Information Knowledge Management & 3 & $4 \%$ \\
\hline Journal of Library Administration & 3 & $4 \%$ \\
\hline Proceedings of The Asia Pacific Conference On Library Information & 3 & $4 \%$ \\
\hline
\end{tabular}

Source: Web of Science database, June 2019

Several KM bibliometric studies such, as Ahmad, JianMing, Rafi, (2018), Ahmadi and Mohammad Nazim (2018), Akhavan, et al. (2016), Kokol et al. (2015), Serenko and Bontis (2017), have identified Journal of Knowledge Management as the most productive publisher of KM research. Surprisingly, this journal has not made it into the top 10 of sources that published articles relating to KM in libraries. However, a co-citation analysis on cited sources showed that the Journal of Knowledge Management was cited 207 times in 36 publications, followed by Journal of Library Management which was cited 74 times in 9 documents. This shows that the Journal of Knowledge Management is a top journal in the field of KM despite it falling short on KM research in libraries (based on WoS). As depicted in Table 5, it shows that KM research pertaining to libraries is likely to be published more in Library Science journals than Knowledge Management journals.

\section{KM Research Contributing Countries}

Figure 5 below shows the ten most prolific countries that published on KM in libraries and information centers. Of the 83 articles analyzed, USA takes a lead with 19 (23\%) publications. This finding corroborates with the finding of Ahmad, JianMing, and Rafi (2018), Ali, Malik and Raza, (2018) and Dwivedi et al., (2011), whose studies also found the USA to be leading in KM research. In this study, USA is followed by South Africa with 12 (14\%) articles, India with 7 (8\%) articles and England with $5(6 \%)$ articles covering KM issues in libraries and information Science. Further analysis on the top three countries (USA, South Africa and India), shows that universities/organizations in these countries provide funding for research projects. This implies that it is necessary for universities, libraries and research funding institutions/agencies to sponsor research especially in this field of KM in libraries where research output is still very low. Research funding would boost KM research in libraries and information centers. Embedding KM in library practices will result in innovative services and increased access to information which is key to economic development. Therefore, it is necessary for funds to be injected in KM research projects in libraries and information centers. 


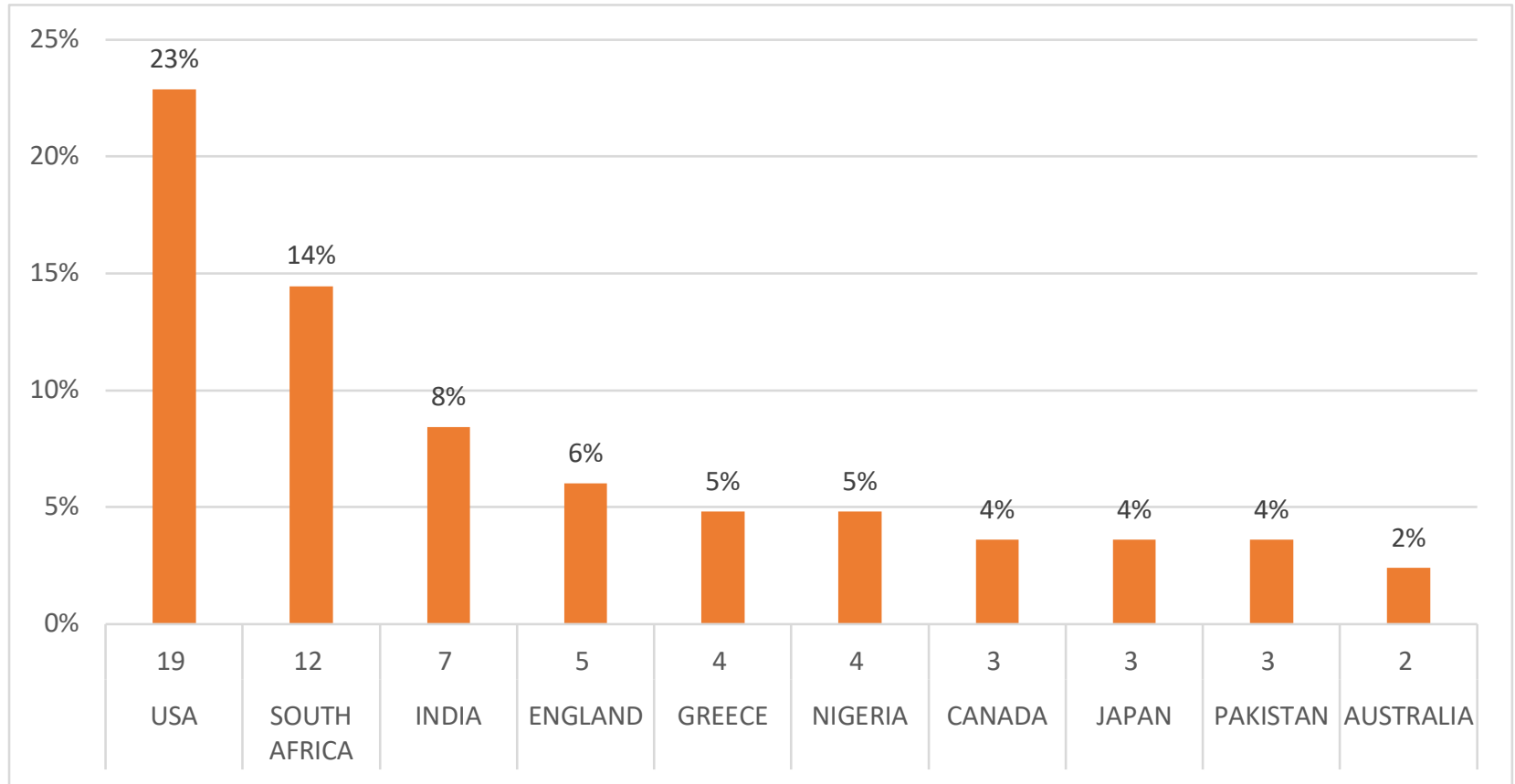

Figure 5: Top $10 \mathrm{KM}$ Research Contributing Countries

Source: Web of Science database, June 2019

\section{Citation Trends}

Citation analysis report shows that since 2000, there were no citations until year 2002. As shown in Figure 6, citations were low from 2002 -2012. This may be attributed to the fact that there was low research activity or publications in the years 2001-2012 as depicted in Figure 1. However, there was an increase in citations in the year 2013 (27 citations) and 2016 (30 citations). The highest number of citations was achieved in 2018 which corroborates with the highest number of publications in 2018 (14 articles published). This may indirectly imply that research activity increased in the years 2016-2019. As of June 2019, there were only 28 citations. In total there were 291 total citations to all 83 items in the result set.

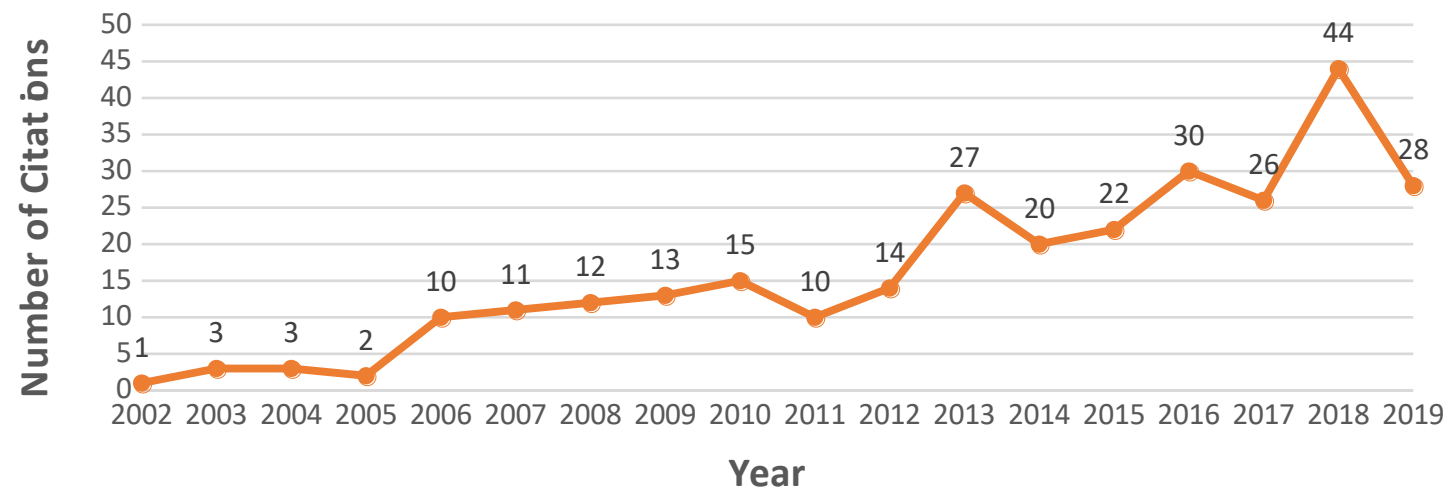

Figure 6: Citations per year

Source: Web of Science database, June 2019 
Jain, P. (2020) Knowledge Management In Libraries And Information Centers: A Bibliometric Perspective. Advances in Social Sciences Research Iournal, 7(4) 431-453.

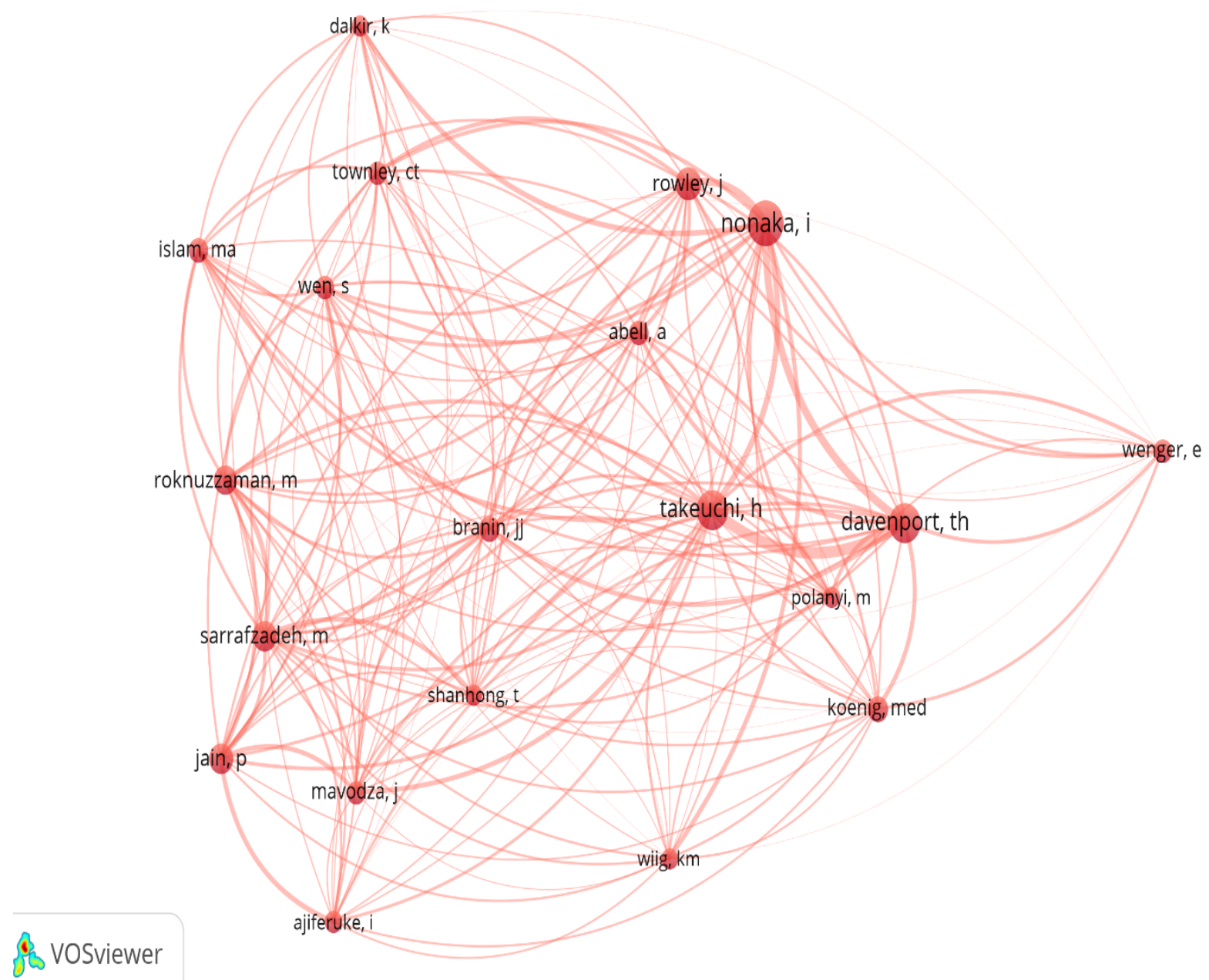

Figure 7: Co-citation network of authors.

In addition, a co-citation analysis of cited authors was conducted results are shown in Figure 7 above. A minimum number of citations of an author was set to '10'. Of 2152 authors, 20 met the threshold. The results as presented in Figure 7, shows that various authors have been co-cited in various documents. There are 188 co-citation connections among the authors, with majority of the authors having 19 co-citation links. The most co-cited author is Nonaka, I. with 35 citations. Takeuchi, H. came second with a co-citation strength of 28. In third place, Davenport, T. H. ranked with 25 citations. These were then followed by Rowley, J. (20 citations), Jain, P. and Sarrafzadeh, M. each with 18 citations. These results are constant with the findings by Gaviria-Marin, Merigó, and Popa (2018), who found out that, Nonaka has the most extensive network and he was also the most cited in the Journal of Knowledge Management. This was also followed by Takeuchi, and Davenport. It is also interesting to note that of all the cited authors Davenport and Takeuchi have the strongest co-citation link of 5.32. Whereas Davenport and Nonaka had a link strength of 3.55, followed by Nonaka and Rowley with a link strength of 2.99. Lastly, Nonaka and Takeuchi were found to have a link strength of 2.56. This shows that these authors are semantically related and hence they have become the most referenced authors in the field of KM. 


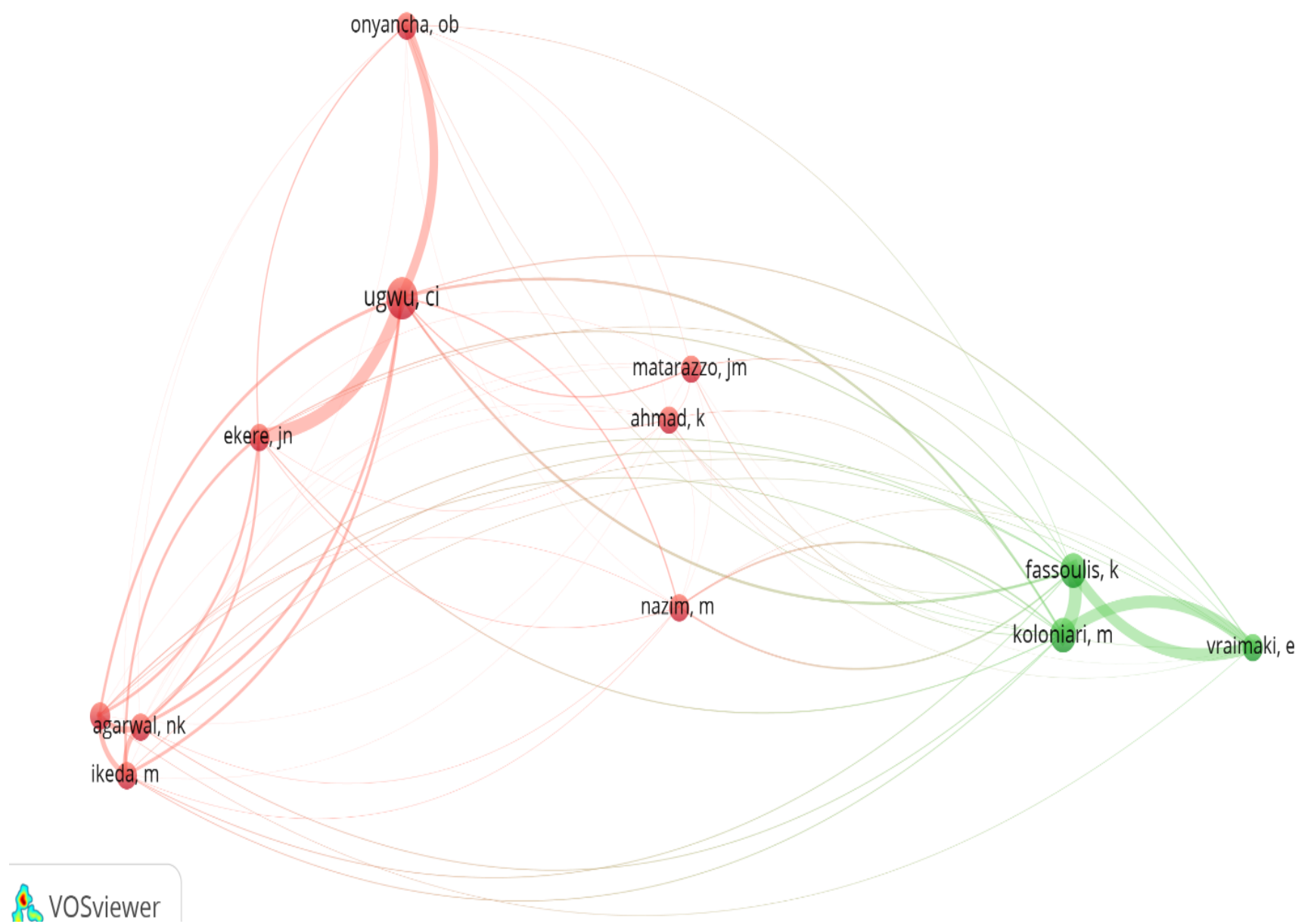

Figure 8: Bibliographic coupling network of authors.

The reverse of co-citation is known as bibliographic coupling. Bibliographic coupling is about the overlap in the reference list of publications. An analysis carried out limited the number of documents of an author to at least '2'. Of 143 authors, 12 met the threshold (Figure 8). Figure 8 confirms the findings in Figure 7 above, which shows that many authors of KM are co-cited. As shown on Figure 8, there is a total of 66 links between authors, with a total link strength of 787.93. More specifically, the strongest bibliographic coupling exists between Fassoulis and Koloniari (128.15 link strength); Ugwu and Ekere (107.41 link strength). The third strongest link exists between Koloniari and Vraimaki (83.71 link strength). It is evident that the larger the number of references two publications have in common, the stronger the bibliographic coupling relation between them. This also proves that the authors with a stronger bibliographic coupling are likely to be treating the same subject, in this case "KM in Libraries".

\section{Keyword Co-occurrence}

A keyword co-occurrence was also conducted based on author used keywords. According to Liao et al. (2018:6), "keywords co-occurrence can effectively reflect the research hotspots in the discipline fields". As a result, the analysis was conducted to see the depth of KM research representation in libraries and to identify the gaps for future research. Author-based keywords were extracted from the 'Title and Abstract' fields using VOSviewer. The first analysis was conducted on keywords with 
Jain, P. (2020) Knowledge Management In Libraries And Information Centers: A Bibliometric Perspective. Advances in Social Sciences Research Iournal, 7(4) 431-453.

a minimum occurrence of ' 5 ', which is a default setting. Only 5 terms met the threshold; academic libraries, university libraries, knowledge management, libraries and librarians. This means that, these were the only keywords with the highest frequency, or which appeared more than 5 times. As a result, the keyword frequency limit was reduced to at least ' 3 ' occurrences, in order to get a bigger sample. Of the 241 author keywords, 18 terms met the threshold as shown on Figure 9. The keyword "Knowledge Management" has a highest frequency of 36, co-occurring with 17 other terms, hence giving it a total link strength of 31.00. Nevertheless, the strongest co-occurrence link of '3.50' exists between the terms "Knowledge Management" and "University library". The second strongest link (3.17) exist between "KM" and "academic library". Followed by "KM" and "Indigenous Knowledge" with a '3.00' link strength. This co-occurrence relationship further affirms the credibility of the abstract screening conducted by the researcher when retrieving sources from the Web of Science database. These keywords prove that relevant documents on KM in Libraries were included in sample.

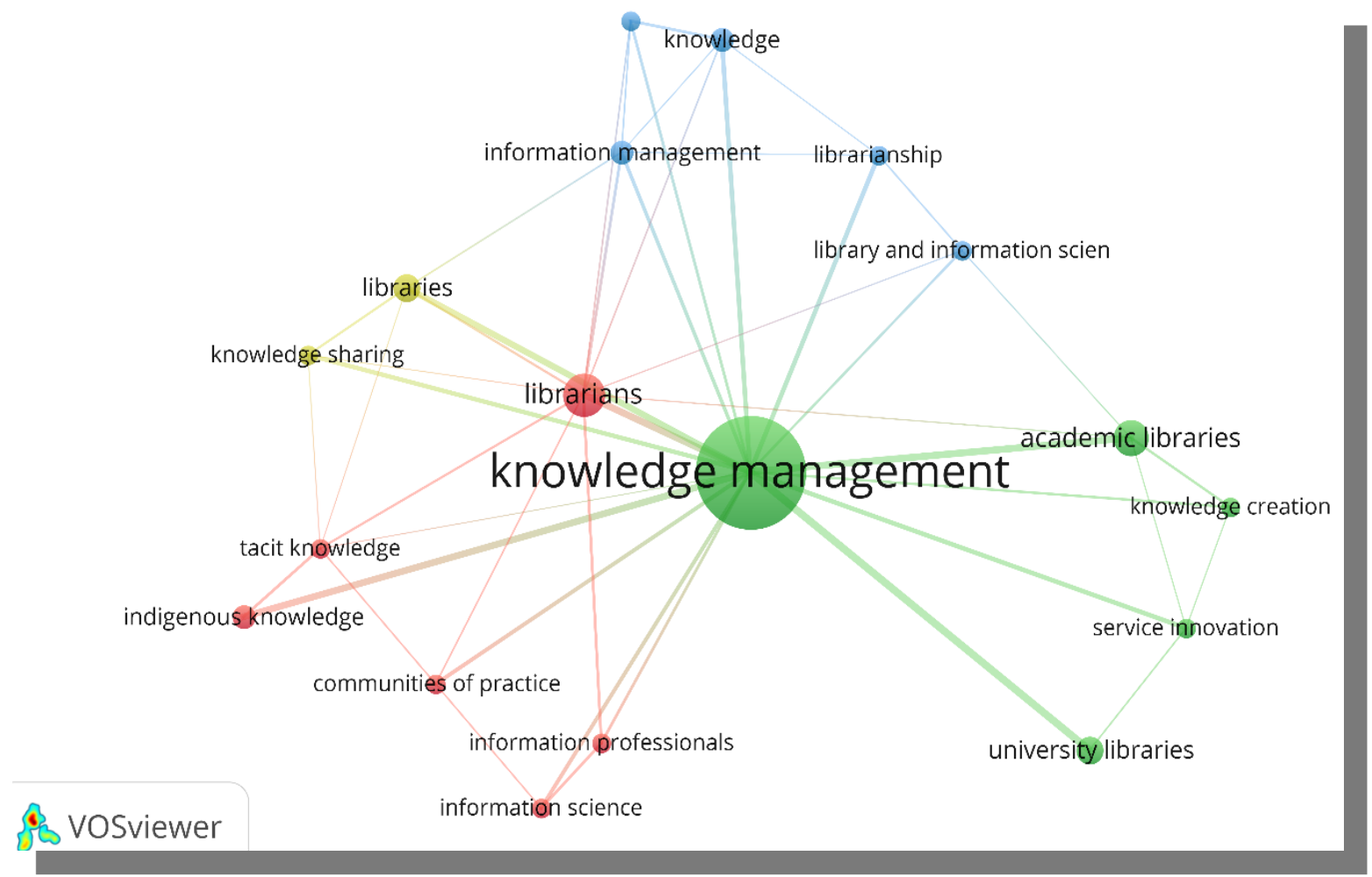

Figure 9: Keyword co-occurrence network

On the other hand, the only aspects of KM covered in the surveyed documents include knowledge sharing, tacit knowledge, indigenous knowledge, and knowledge creation (Figure 9). It is therefore, evident that the research in KM in libraries and information centers is very shallow. As a result, there is a research gap and opportunity for future research. As demonstrated by other scholars, KM is a diverse discipline with numerous concepts. Examples include, Ahmadi and Nazim (2018), Gaviria-Marin, Merigó, Popa (2018), Sedighi and Jalalimanesh (2014), who identified the following keywords on KM; data mining, knowledge management, human capital, knowledge representation, organizational culture, organizational learning, knowledge transfer, social capital, intellectual capital, knowledge creation, classification, knowledge discovery, innovation, risk assessment, clustering, machine learning, knowledge, knowledge sharing, knowledge acquisition, ontology and 
education. These range of keywords show that there are future opportunities for researchers to evaluate the knowledge management infrastructure in libraries. Thus, there is still more to be explored in the field of KM in libraries.

\section{CONCLUSION}

From the foregoing, it could be concluded that a bibliometric analysis of KM literature is important in gaining insight of the existing literature, trending in research publications, to determine the impact factor, find out the roles and contributions of institutions, countries, authors and research publishers in the field of $\mathrm{KM}$ in libraries and information centers. The study identified most productive year for KM research in libraries as 2018 and most productive research institution was University of South Africa. The study further revealed the most prolific author was C.I. Ugwu; most research outcomes were disseminated through journal publications; USA led in KM research; the highest number of publications and citations corroborated in 2018 and collaborative research were found more widespread than single authored.

A search string that included all the disciplines retrieved 107,042 articles. This shows that KM research is active in all disciplines. After setting the search criteria to retrieve documents only from the library and information Science discipline as categorized by Web of Science, 2,854 articles were retrieved. While with combination of two sets with different search strings retrieved 310 publications specific to KM in libraries or information centers. Further analyses conducted by screening the abstract to select the most relevant sources obtained only 83 publications in KM in the field of library and information centers. These findings show that KM research in libraries is not yet prominent; hence, there is a need for more research in KM in the field of library and information centers.

\section{RECOMMENDATIONS}

Based on the findings of the study, the following recommendations are put forward:

- Research on knowledge management application: The findings of this small-scale study revealed there is scarcity of the literature on the success stories of KM implementation in libraries and information centers. Most of the KM research is undertaken on the concepts, perceptions, and how KM can be applied in the libraries and information centers. There is a need for more research on KM actual implementation and its impact in libraries and information centers.

- Need for a comprehensive research: This study was based only on ISI Web of Science's Core collection database and it was limited only to 4 types of document categories: 1 articles, 2 book chapters, 3 conference papers, and 4. book reviews. Many knowledge management research outputs published in libraries and information centers field might have been missed due to the above limitations. Hence, a more comprehensive research using a database like Scopus should be undertaken to provide a broader picture on KM literature in libraries.

- Dissemination of research findings at conferences: The findings of the study revealed that only $7 \%$ sources were retrieved from the conference proceedings. It is recommended that more research findings should be disseminated through conference platforms. 
Jain, P. (2020) Knowledge Management In Libraries And Information Centers: A Bibliometric Perspective. Advances in Social Sciences Research Iournal, 7(4) 431-453.

Conferences create academic debates among professionals, which facilitates development of practice-based strategies and research is transformed into practice rather than theory.

- Research Funding: The findings of the study showed that most prolific countries that published on KM in libraries and information centers were USA, South Africa, India and England, whose institutions were funding for KM research. It is recommended therefore, that universities, libraries and research funding institutions/agencies should sponsor for research to boost KM research in libraries and information centers. Practicing KM in libraries and information centers will result in innovative services and increased access to information leading towards economic development.

\section{References}

[1] Abell, A. 2000. Skills for knowledge environments. Information Management Journal, Vol. 34, no.3: 10-12.

[2] Abualoush, S., Masa'deh, R., Bataineh, K., and Alrowwad, A. 2018. The role of knowledge management process and intellectual capital as intermediary variables between knowledge management infrastructure and organization performance. Interdisciplinary Journal of Information, Knowledge, and Management, Vol.13: 279-309.

[3] Agarwal, N. K. and Islam, M. A. 2014. Knowledge management implementation in a library: Mapping tools and technologies to phases of the KM cycle. The Journal of Information and Knowledge Management Systems, Vol.44, no.3: 322-344.

[4] Ahmad, K. JianMing, Z. and Rafi, M. 2018. Assessing the literature of knowledge management (KM) in the field of library and information science. Information Discovery and Delivery, Vol.47: no.1: 35-41.

[5] Ahmadi, A. and Nazim, M. 2018. Changing trends in Knowledge Management research from Library and Information Science perspective. IFLA KM Satellite Meeting on 23.08.2018. Available at: http://library.ifla.org/2418/1/s05-2018-ahmadi-en.pdf.

[6] Ajie, I. 2019. Issues and Prospects of Knowledge Sharing in Academic Libraries. Library Philosophy and Practice (e-journal), 2521. Available at:

https://digitalcommons.unl.edu/cgi/viewcontent.cgi?article=5805\&context=libphilprac

[7] Akhavan, P., Ebrahim, N. A., Fetrati, M. A., and Pezeshkan, A. 2016. Major trends in knowledge management research: a bibliometric study. Scientometrics, Vol.107, no.3: 249-1264.

[8] Akhavan, P., Ramezan, M. and Moghaddam, J. Y. 2013. Examining the role of ethics in knowledge management process, case study: An industrial organization, Journal of Knowledge-Based Innovation in China, Vol.5, no.2: 129-145.

[9] Alajmi, B. and Alhaji, T. 2018. Mapping the Field of Knowledge Management: Bibliometric and Content Analysis of Journal of Information \& Knowledge Management for the Period from 2002-2016. Journal of Information \& Knowledge Management, Vol.17, no.3. DOI: 10.1142/S0219649218500272

[10] Ali, P. M. N. and D. Khan. 2017. Investigating Knowledge Management Strategies in Central University Libraries in India. Journal of Library \& Information Technology, Vol.37, no.2: 73-78.

[11] Ali, P. M. N., Malik, B. A. and Raza, A. 2018. Bibliometric analysis of literature on knowledge sharing. Annals of Library and Information Studies, Vol.65: 217-227.

[12] Asogwa, B. E. 2012. Knowledge Management in Academic Libraries: Librarians in the 21st Century. Journal of Knowledge Management Practice, Vol.13, no.2. Available at: http://www.tlainc.com/articl301.htm

[13] Awodoyin, A., Osisanwo, T., Adetoro. N., and Adeyemo, I. 2016. Knowledge Sharing Behaviour Pattern Analysis of Academic Librarians in Nigeria, Journal of Balkan Libraries Union, Vol.4, no.1: 12-19. DOI: 10.16918/bluj.39024

[14] Barron, D.D. 2000. Knowledge management for the next millennium: the next step for school library media specialists. School Library Media Activities Monthly, Vol.16, no.5: 48-51. 
Advances in Social Sciences Research Journal (ASSRJ)

Vol.7, Issue 4, Apr-2020

[15] Bem, R. M., and Coelho, C. C. 2013. Applications of knowledge management in the area of librarianship and information science: a systematic review. Brazilian Journal of Information Science, Vol.7, no.1: 67-93.

[16] Chao, C.-C., Yang, J.-M., and Jen, W. Y. 2007. Determining technology trends and forecasts of RFID by a historical review and Bibliometric analysis from 1991 to 2005. Technovation, Vol. 27: 268-279.

[17] Chauvel, D. and Despres, C. 2002. A review of survey research in knowledge management: 1997-2001. Journal of Knowledge Management, Vol.6, no.3: 207-223. D0I: 10.1108/13673270210434322

[18] Choo, C.W. 2000. Working with knowledge: how information professionals help organisations manage what they know. Library Management, Vol.21, no.8: 395-403.

[19] Dattero, R. 2006. Collaboration between the top knowledge management/intellectual capital researchers. Knowledge and Process Management, Vol.13, no.4: 264-269.

[20] Durieux, V. and Gevenois, P. A. 2010. Bibliometric indicators: quality measurements of scientific publication. Radiology, Vol.255, no.2: 342-351.

[21] Dwivedi, Y., Venkitachalam, K., Sharif, A., Al-Karaghouli, W. and Weerakkody, V. 2011. Research trends in knowledge management: analyzing the past and predicting the future. Information Systems Management, Vol.28, no.1: 43-56. DOI: $10.1080 / 10580530.2011 .536112$

[22] Evans, A. and McKinley, M. 2010. Paradigm and paradox: knowledge management and business ethics. International Scholarly and Scientific Research \& Innovation, Vol.4, no.6: 1098-1104.

[23] Fteimi, N. and Lehner, F. 2016. Main Research Topics in Knowledge Management: A Content Analysis of ECKM Publications. The Electronic Journal of Knowledge Management, Vol.14, no.1: 5-17.

[24] Gaviria-Marin, M., Merigó, J. M. and Baier-Fuentes, H. 2019. Knowledge management: A global examination based on bibliometric analysis. Technological Forecasting \& Social Change, Vol.140: 194-220. DOI:

0.1016/j.techfore.2018.07.006

[25] Gaviria-Marin, M., Merigó, J. M., Popa, S. 2018. Twenty years of the Journal of Knowledge Management: a bibliometric analysis. Journal of Knowledge Management, Vol. 22, no. 6: 1655-1687. DOI: 10.1108/JKM-10-20170497.

[26] Gu, Y. 2004. Global knowledge management research: A bibliometric analysis. Scientometrics, Vol. 61, no.2: 171190. DOI: 10.1023/B:SCIE.0000041647.01086.f4

[27] Iqbal, J. and Mahmood, Y. 2012. Reviewing Knowledge Management Literature. Interdisciplinary Journal of Contemporary Research in Business, Vol.4, no. 6: 1005-1026.

[28] Jain, P. 2013. Knowledge Management in Academic Libraries and Information Centres: A Case of University Libraries. Journal of Information \& Knowledge Management, Vol.12, no.4, DOI: 10.1142/S0219649213500342

[29] Koina, C. 2003. Librarians are the ultimate knowledge managers? The Australian Library Journal, Vol.52, no.3: 269-72.

[30] Kokol, P. et al. 2015. Knowledge Management in Organizations - A Bibliometric Analysis of Research Trends. Proceedings of the $10^{\text {th }}$ International Conference KMO 2015, Lecture Notes in Business Information Processing, Springer, 224: 3-14, 2015. DOI: 10.1007/978-3-319-21009-4_1.

[31] Koloniari, M. and Fassoulis, K. 2017. Knowledge management perception in academic Libraries. Journal of Academic Librarianship, Vol.43, no.2: 135-142. DOI: 10.1016/j.acalib.2016.11.006

[32] Kör, B. 2017. Revealing Trends in Knowledge Management Research: From 2010 to 2015. Istanbul University Journal of the School of Business, Vol. 46: 18-30.

[33] Lang, T., Hall, D. and Landrum, W. Heath 2010. Citation Analysis and Trends in Knowledge Management. In Americas Conference on Information Systems (AMCIS) 2010 Proceedings. Paper 90. Lima, Peru, August 12-15, 2010. Available at: https://pdfs.semanticscholar.org/bd43/aa8433d5d70da37a8313d1f56d80a3ba314a.pdf

[34] Lee, M. R. and Chen, T. T. 2012. Revealing research themes and trends in knowledge management: From 1995 to 2010. Knowledge-Based Systems, Vol.28: 47-58. DOI: 10.1016/j.knosys.2011.11.016. 
Jain, P. (2020) Knowledge Management In Libraries And Information Centers: A Bibliometric Perspective. Advances in Social Sciences Research Iournal, 7(4) 431-453.

[35] Liao, H., Tang, M., Luo, L., Li, C., Chiclana, F. and Zeng, X.-J. 2018. A Bibliometric Analysis and Visualization of Medical Big Data Research. Sustainability, Vol. 10. DOI: 10.3390/su10010166

[36] Maruf, H., and Zhou, S. 2015. Knowledge management in global organization. International Business Research, Vol. 8, no. 6: 165-173.

[37] Mašić, B., Nešić, S., Nikolić, D., Dželetović, M. 2017. Evolution of knowledge management. Industrija, Vol.45, no.2: 127-147. DOI: $10.5937 /$ industrija45-13201

[38] Mavodza, J. and Ngulube, P. 2011. Exploring the use of knowledge management practices in an, Academic library in a changing information environment. South African Journal of Libraries and Information Science, Vol.77, no.1: 15-25.

[39] Nazim, M. 2013. Librarians' perceptions of knowledge management in developing countries: A case with Indian academic libraries. The International Information \& Library Review, Vol.45, no. 1: 63-76. DOI:

10.1016/j.iilr.2013.08.002

[40] Nazim, M. and Mukherjee, B. 2011. Implementing Knowledge Management in Indian Academic Libraries. Journal of Knowledge Management Practice, Vol.12, no.3. Available at: http://www.tlainc.com/articl269.htm (Accessed 17 October 2019).

[41] O'dell, C. C. Grayson and N. Essaides 1998. If only we knew what we know: The transfer of internal knowledge and best practice. New York: Free Press.

[42] Onyancha, Omwoyo Bosire 2006. Trends and patterns of 'Knowledge Management' research in South Africa: an informetric analysis of tacit and explicit knowledge management: an informetric analysis of tacit and explicit knowledge management literature. Paper presented at the XVII Standing Conference of Eastern, Central \& Southern Africa Library \& Information Associations (SCECSAL XVII), July 2006, at Dar es Salaam, Tanzania.

[43] Poonkothai, R. 2016. Knowledge Management as an important tool in Library Management. International Journal of Information Technology and Library Science, Vol.5, no.1: 9-14.

[44] Qiu, J. and Lv, H. 2014. An overview of knowledge management research viewed through the web of science (1993-2012). Aslib Journal of Information Management, Vol.66, no.4: 424-442. DOI: 10.1108/AJIM-12-2013-0133

[45] Rooi, H., Snyman, R. 2006. A content analysis of literature regarding knowledge management opportunities for librarians. Aslib Proceedings, Vol.58, no.3: 261-271. DOI: 10.1108/00012530610677255

[46] Rusuli M. S. C, Tasmin, R., and Takala, J. 2012. The Impact of Structural Approach on Knowledge Management Practice (KMP) at Malaysian University Libraries. Australian Journal of Basic and Applied Sciences, Vol.6, no. 10: 122128.

[47] Sarrafzadeh, M., Martin, B. and Hazeri, A. 2010. Knowledge management and its potential applicability for libraries. Library Management, Vol.31, no.3: 198-212. DOI: 10.1108/01435121011027363

[48] Sedighi, M. and Jalalimanesh, A. 2014. Mapping research trends in the field of knowledge management. Malaysian Journal of Library \& Information Science, Vol.19, no.1: 71-85.

[49] Serenko, A. 2013. Meta-analysis of Scientometrics research of knowledge management: discovering the identity of the discipline. Journal of Knowledge Management, Vol.17, no.5: 773-812. DOI: 10.1108/JKM-05-2013-0166.

[50] Serenko, A. and Bontis, N. 2013. The intellectual core and impact of the knowledge management academic discipline, Journal of Knowledge Management, Vol.13, no.1: 137-155. DOI: 10.1108/13673271311300840

[51] Serenko, A. and Bontis, N. 2017. Global ranking of knowledge management and intellectual capital academic journals: 2017 update. Journal of Knowledge Management, Vol.21, no.3, pp. 675-692. DOI: 10.1108/JKM-11-2016-0490

[52] Serenko, A., Bontis, N., Booker, L., Sadeddi, K. and Hardie, T. 2010. A scientometric analysis of knowledge management and intellectual capital academic literature (1994-2008). Journal of Knowledge Management, Vol.14, no.1: 3-23. DOI: $10.1108 / 13673271011015534$

[53] Serenko, A., and Dumay, J. 2015. Citation classics published in knowledge management journals. Part I: articles and their characteristics. Journal of Knowledge Management, Vol.19, no.2: 401-431. 
[54] Sirorei, E. C. and Fombad, M. C. 2019. Knowledge management processes at St Paul's University Library in Kenya. South African Journal of Information Management, Vol. 21, no.1. DOI: 10.4102/sajim.v21i1.946

[55] Sohail, N. 2008. Literature on knowledge management in library and information science (1999-2006): A bibliometric study. Master's Thesis, Aligarh Muslim University.

[56] Ugocha, O. C., Igwe, K.N. and Ibenne, S. K. 2018. Knowledge Sharing Among Librarians: A Literature Review. International Journal of Applied Technologies in Library and Information Management, Vol.4, no.1: 78-89.

[57] Ugwu, C. I., and Ekere, J. N. 2017. Knowledge management for improving services in federal university libraries in Nigeria. Journal of Librarianship and Information Science, Vol.51, no.2: 356-369. DOI: 10.1177/0961000617742446

[58] Wanangeye, W. L. and George, B. 0. 2016. Knowledge Management Practices and Performance of Academic Libraries: A Case of Mount Kenya University, Kigali Campus Library. World Journal of Computer Application and Technology, Vol.4, no.2: 34-39. DOI: 10.13189/wjcat.2016.040202

[59] Wang, P., Zhu, F.-W., Song, H.-Y., Jian-Hua Hou, J.-H. and Zhang, J.-L. 2018. Visualizing the Academic Discipline of Knowledge Management. Sustainability, Vol.10, No.3: 1-28. DOI: 10.3390/su10030682 